\title{
Impact of invasion by molasses grass (Melinis minutiflora P. Beauv.) on native species and on fires in areas of campo-cerrado in Brazil
}

Rafael Drumond Rossi ${ }^{1,5}$, Carlos Romero Martins ${ }^{2}$, Pedro Lage Viana ${ }^{3}$, Evandro Luís Rodrigues ${ }^{4}$ and José Eugênio Côrtes Figueira ${ }^{1}$

Received: October 17, 2013. Accepted: June 30, 2014.

\begin{abstract}
In the Cerrado Biome of Brazil, African grasses constitute a serious problem, occurring in virtually all protected areas. Molasses grass (Melinis minutiflora P. Beauv.) accumulates more biomass than do most other species of the herbaceous stratum vegetation native to the Cerrado. In this study, our aim was to determine the impact of M. minutiflora on native vegetation, as well as (using simulations of fire traits) on the characteristics of fires, in invaded areas of the Serra do Rola-Moça State Park (Parque Estadual da Serra do Rola-Moça, PESRM), a protected area where fires are frequent, in the state of Minas Gerais, Brazil. Our main results are that M. minutiflora considerably increases the amount of biomass, becoming the main combustible plant in the campo-cerrado (grassy-woody savanna) fires in the PESRM; that the native monocot biomass is inversely correlated with the M. minutiflora biomass, suggesting suppression of the native herbaceous stratum; that eudicots are diminished by $M$. minutiflora, both in number of individuals and number of species; and that fires are more severe in M. minutiflora-invaded areas.
\end{abstract}

Key-words: Cerrado, BehavePlus, biological invasion, fire intensity, savannah

\section{Introduction}

The most economically important cattle forage grass species in the Neotropics are those native to Africa (Parsons 1972). African grasses are also used for recovery of degraded areas and as slope cover along highway and railway embankments (Reis et al. 2003; Martins 2006). They are easily exportable due to their invasive characteristics (Foxcroft et al. 2010), causing a global problem (Hughes et al. 1991; Barger et al. 2003; Martins 2006; Dogra et al. 2010; Foxcroft et al. 2010) through biological contamination of natural ecosystems (Espíndola et al. 2005). In Brazil, African grasses were introduced during the colonization period of the 16th century (Diamond 1999; Zenni \& Ziller 2011) and were commonly used for pasture after deforestation (Parsons 1972; Fearnside 2005). Owing to their great ability to invade open areas, they also became a serious problem in the Cerrado Biome (Pivello 2014), becoming common in several of its protected areas (Pivello et al. 1999a; 1999b). The African grass Melinis minutiflora P. Beauv. (molasses grass), widely distributed in South America, Hawaii, Australia, Central America, Asia and Oceania (Hughes et al. 1991; Barger et al. 2003; Martins
2006), is commonly found in Brazil (Pivello 2014), where it had been the most commonly used species for pastures until the beginning of the 1970s, when programs to replace it with more productive grasses began (Martins 2006). Its introduction into the state of Minas Gerais most likely dates back to the 18th century (Biodiversitas et al. 2006).

Although the genus Melinis P. Beauv. comprises 22 species (The Plant List, 2014), only M. minutiflora and M. repens (Willd.) C. E. Hubb. occur in Brazil (Biodiversitas et al. 2006; Filgueiras et al. 2010). Molasses grass grows vigorously in the nutrient-poor and aluminum-rich soils of the Cerrado Biome (Gonçalves \& Borges 2006; Martins et al. 2011). It blooms at the beginning of the dry season, in mid-May, producing large amount of seeds with a germination rate of approximately $90 \%$ (Alcântara \& Bufarah 1951; Martins 2006; Carmona \& Martins 2009). Studies within different ecosystems around the world indicate that molasses grass can form dense cover in invaded areas, changing nutrient cycles, light availability and soil microclimate (Barger et al. 2003), thus slowly replacing native species of the herbaceous stratum (Martins et al. 2004; Martins et al. 2009). Because of its higher biomass accumulation

\footnotetext{
${ }^{1}$ Universidade Federal de Minas Gerais, Instituto de Ciências Biológicas, Departamento de Biologia Geral, Avenida Antônio Carlos no. 6.627, Pampulha, Belo Horizonte, MG, Brasil - CEP: 31.270-901.

${ }^{2}$ IBAMA/DILIC, SCEN Trecho 2, Ed. Sede do IBAMA, Brasília, DF, Brasil - CEP: 70.818-900.

${ }^{3}$ Museu Paraense Emílio Goeldi. Avenida Magalhães Barata, 376, São Braz, Belém - PA, 66040-170, Brasil.

${ }^{4}$ Universidade Federal de Minas Gerais, Instituto de Geociências, Avenida Antônio Carlos n. ${ }^{\circ}$ 6.627, Pampulha, Belo Horizonte, MG, Brasil - CEP: 31.270-901.

${ }^{5}$ Author for correspondence: rafeldr@gmail.com
} 
rates, compared to those of the native herbaceous stratum (Berardi 1994; Silva \& Haridasan 2007), and its abundant oil secretions (Prates et al. 1993), this grass can also change fire regimes in invaded areas, promoting its further expansion in a feedback mechanism known as the "grass-fire cycle" (Hughes et al. 1991; D’Antonio \& Vitousek 1992).

In the Cerrado Biome, several important protected areas suffer from invasion by molasses grass. Some of these are the Brasília National Park, the world's largest natural conservation area in an urban environment (Martins 2006; Zanin 2009); the Emas National Park, an important reserve in the Central Plateau (França et al. 2007); and the Serra do Rola-Moça State Park (Parque Estadual da Serra do Rola-Moça, PESRM), which protects areas of the Cerrado in the iron-stone vegetation and areas of the Atlantic Forest (Biodiversitas et al. 2006). The PESRM is considered a priority area for biodiversity conservation in the state of Minas Gerais because of its high levels of biodiversity and endemism. Large patches of molasses grass in this park increase its vulnerability to fire, one of its main threats (Biodiversitas et al. 2006). However, the impact of molasses grass on native vegetation and its effects on fire properties have been largely unevaluated.

In an attempt to address parts of this knowledge gap, this study had the following goals: to determine whether native species are being suppressed due to invasion of molasses grass; to assess the magnitude of the increase in combustible plant biomass resulting from the molasses grass spread in an area of the grassy-woody savanna (campo-cerrado) vegetation; and to simulate and compare characteristics of fires in the campo-cerrado areas with different degrees of molasses grass invasion.

\section{Material and Methods}

\section{Study area}

The PESRM is located in the northwestern part of the region known as the Iron Quadrangle, a transition area between the Atlantic Forest and the Cerrado Biomes, in the metropolitan area of Belo Horizonte, the capital of Minas Gerais. The main vegetation formations found in the PESRM are the semideciduous forest; the woody savanna (cerradão); the grassy-woody savanna (campo-cerrado, or cerrado sensu stricto); and the sandstone and ironstone grasslands. Molasses grass is found in all of those formations, with the exception of the semideciduous forest. The climate of the region is mesothermal, characterized by an annual mean temperature of $25^{\circ} \mathrm{C}$, high daily thermal variation, high winds, and a dry season from April to September (Biodiversitas et al. 2006). The molasses grass patches studied are located near the park headquarters $\left(20^{\circ} 03^{\prime} 07.1^{\prime \prime} S\right.$; $44^{\circ} 00^{\prime} 00.0^{\prime \prime} \mathrm{W}$ ). The campo-cerrado vegetation is predominant in the study areas, with sparse trees embedded in an extensive matrix of grasslands.

\section{Biomass increase and elimination of native monocots}

Vegetation sampling was carried out in April and May 2009 . Twenty plots of $0.5 \times 0.5 \mathrm{~m}$ were randomly selected in a campo-cerrado field invaded by molasses grass and protected from fires for over 13 years. The vegetation within each square was cut at ground level, collected, bagged in 100-L plastic bags and taken to the laboratory. In the laboratory, the biomass was separated into live and dead fractions of its various components: molasses grass; native monocots; native eudicots; and litter (composed of dry fragments of grass blades, stems, etc.) The biomass components were then dried in an oven at temperatures of approximately $60^{\circ} \mathrm{C}$ to a constant weight, after which they were weighed with a precision balance. The monocot species of the study area were identified from the specialized literature and by comparison with specimens at the Herbarium of the Federal University of Minas Gerais, in Belo Horizonte (BHCB).

Linear regression, Pearson's correlation coefficient or both were used in order to test the hypotheses that molasses grass is the main component of the total biomass, leads to the biomass reduction of native monocots and is correlated with a large increase in the amount of litter found in the plots. To compare the standing dead biomass between the native grasses and molasses grass, we used ANCOVA. When necessary, log transformations were used in order to linearize the data or to homogenize variances and normalize residuals.

\section{Elimination of eudicots}

From June to August 2011, vegetation sampling was also carried out at other field patches that had been invaded, or not, by molasses grass and protected from fires for over fifteen years. Linear transects were set in invaded and noninvaded patches, and samples of all eudicots in $0.7 \times 0.7$ $\mathrm{m}$ plots, one meter apart, were collected. The size of the molasses grass patches limited the number of plots sampled in each area. There were 50 plots sampled for each condition (invaded vs. non-invaded) in area 1; 100 plots for each treatment in areas 2 and 3; and 70 plots for each treatment in area 4. All eudicots were identified, and the number of individuals of each species for each plot (sampling unit) were determined in order to estimate the species richness in the invaded and non-invaded areas, with the richness estimator index ACE (abundance-based coverage estimator). To compare the density of species in invaded and non-invaded transects, we used the Mann-Whitney U test.

\section{Fire simulations}

The BehavePlus Fire Modeling System is a collection of over 40 semi-physical models described in 58 reference papers that predict wildland fire behavior and its environmental effects. It is among the most widely used systems 
for wildland fire prediction. Planning prescribed fires, fuel hazard assessment, and training are among the BehavePlus applications (Andrews 2009; 2014). Using the BehavePlus, Mistry \& Berardi (2005) obtained results substantiated by previous studies in the cerrado fires. Fernandes (2003) did simulation with BehavePlus in the PESRM and also obtained satisfactory results. The lowest relative air humidity $(11 \%)$, and mean wind speeds $(13.9 \pm 8.7 \mathrm{~km} / \mathrm{h})$ in August of the years 2011, 2012 and 2013 (data from the A555 Ibirité-Rola-Moça meteorological station: www. inmet.gov.br), were used for the input data in BehavePlus, in order to compare the expected fire behavior in the campo-cerrado fields without molasses grass $(5.6 \mathrm{Mg} / \mathrm{ha})$, with the intermediate invasion $(14.0 \mathrm{Mg} / \mathrm{ha})$ and the high invasion rate $(18.4 \mathrm{Mg} / \mathrm{ha})$. The biomass surface/volume ratio and biomass energy content were obtained from Mistry \& Berardi (2005). Since dead biomass moisture and wind speeds depend on climate conditions, and the moisture of dead grasses and air can reach equilibrium in approximately one hour (Fernandes 2003), simulations were performed with mean wind speeds of 5, 10 and 15 $\mathrm{km} / \mathrm{h}$, and the dead biomass moisture ranged from 8 to $23 \%$. These value ranges allow for a direct comparison with the findings of Mistry \& Berardi (2005). For simplicity, the topography was considered plane.

\section{Results}

\section{Biomass increase and elimination of monocots}

Apart from molasses grass, seven native monocot species were found in the studied area: six species of Poaceae ( $A n$ dropogon sp., Anthaenantia lanata (Kunth) Benth., Aristida recurvata Kunth, Axonopus siccus Kuhlm, Paspalum sp., and Schizachyrium microstachyum (Desv. ex Ham.) Roseng., B.R. Arrill. \& Izag.); and one of Iridaceae (Sisyrinchium vaginatum Spreng.). No other invasive species were found.

The rate of accumulation of the standing dead biomass of native grasses was similar to that of molasses grass (Fig. 1). However, the combined live and standing dead biomasses of molasses grass were greater than were those of native grasses (Fig. 1), indicating a greater contribution of the former to the fine fuel accumulation. The maximum total biomass in the areas invaded by molasses grass was $18.4 \mathrm{Mg} / \mathrm{ha}$, or 3.3 times greater than the $5.6 \mathrm{Mg} / \mathrm{ha}$ in the non-invaded areas. As can be seen in Fig. 2, molasses grass became the main biomass component in the areas it invaded, correlating strongly with the total biomass in the plots $(r=0.756)$. The native monocot biomass decreased in proportion to the increase in molasses grass (native monocot biomass $=69.70-0.30$ molasses grass, $\mathrm{r}=-0.547, p<0.05$ ). Litter, another important component of the total biomass, was strongly correlated with the molasses grass biomass in each plot (litter biomass $=36.98+0.66$ molasses grass biomass, $\mathrm{r}=0.636, p<0.05)$.

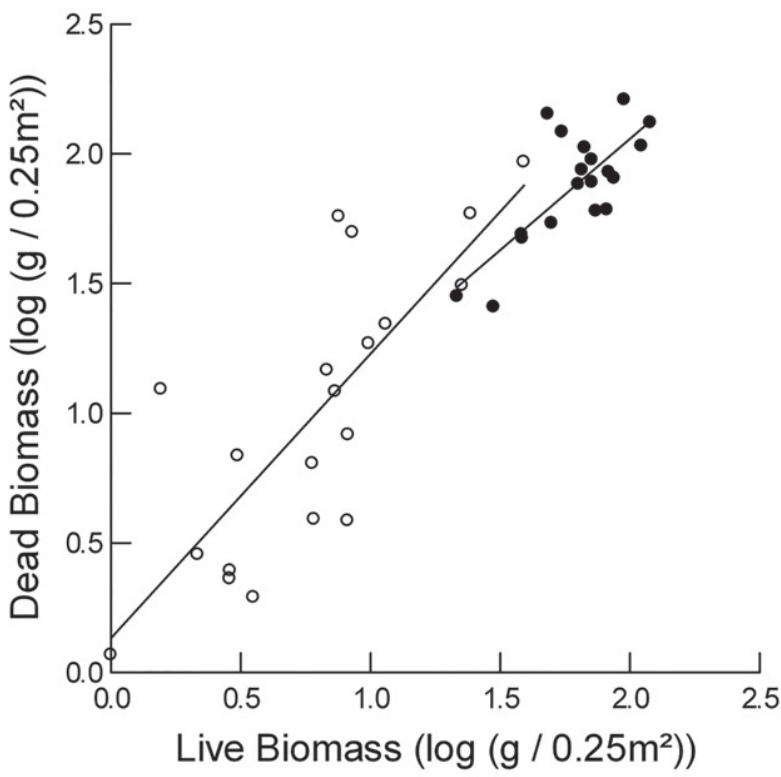

Figure 1. Relationships between standing dead and live biomasses of molasses grass (filled circles) and native grasses (open circles). ANCOVA: $p=0.950$ for the intercept, and $p=0.887$ for the angular coefficient.

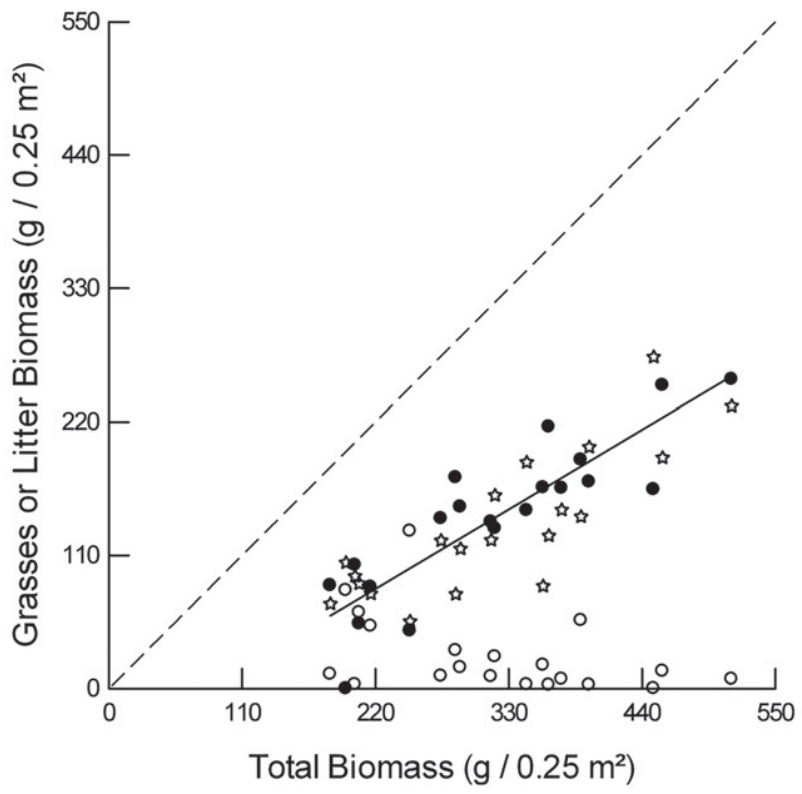

Figure 2. Contribution of molasses grass (filled circles, continuous line), native grasses (open circles) and litter (stars) to the biomass of the campos-cerrado grass layer (dashed line).

\section{Elimination of eudicots}

Taking into account all recorded species of eudicots, molasses grass reduced their individual numbers in the four invaded areas between 1.8 and 4.1 times (Tab. 1). The richness estimator index ACE (abundance-based coverage estimator) indicated a reduction in the number of species 
Table 1. Comparison of eudicot counts in areas invaded (INV) and non-invaded (NAT) by molasses grass.

\begin{tabular}{|c|c|c|c|c|c|c|c|c|}
\hline 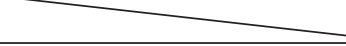 & INV 1 & NAT 1 & INV 2 & NAT 2 & INV 3 & NAT 3 & INV 4 & NAT 4 \\
\hline Number of Squares & \multicolumn{2}{|c|}{50} & \multicolumn{2}{|c|}{100} & \multicolumn{2}{|c|}{100} & \multicolumn{2}{|c|}{70} \\
\hline Total Number of Individuals & 129 & 322 & 55 & 209 & 145 & 591 & 224 & 407 \\
\hline Average Number of Individuals & 2.58 & 6.44 & 0.55 & 2.09 & 1.45 & 5.91 & 3.20 & 5.81 \\
\hline Standard Deviation & 1.46 & 2.03 & 0.86 & 1.52 & 1.42 & 2.70 & 2.10 & 2.98 \\
\hline Wilcoxon (Z) & \multicolumn{2}{|c|}{5,889} & \multicolumn{2}{|c|}{6,753} & \multicolumn{2}{|c|}{8,497} & \multicolumn{2}{|c|}{5,533} \\
\hline P-Valor & \multicolumn{2}{|c|}{$<0.001$} & \multicolumn{2}{|c|}{$<0.001$} & \multicolumn{2}{|c|}{$<0.001$} & \multicolumn{2}{|c|}{$<0.001$} \\
\hline
\end{tabular}

in the four studied areas invaded by molasses grass (Fig. 3). The reduction was estimated to be between 16\% (Area 2) and $43 \%$ (Area 4 ), with a mean of $33 \%$. Species density was higher in non-invaded areas (6.3 species $/ \mathrm{m}^{2}$ vs. 2,6 species/ $\mathrm{m}^{2}$, Mann-Whitney $\mathrm{U}$ test: $\left.p<0.001\right)$. Species sensitivity to the molasses grass invasion is listed in Tab. 2.

\section{Fire simulations}

Simulations with the BehavePlus 5 indicated that fires would be more destructive in the fields invaded by molasses grass (Fig. 4 and 5). From 2010 to 2013, the relative air humidity was $\leq 18 \%$ on 13 days. Considering the more critical periods with $18 \%$ dead biomass moisture and $15 \mathrm{~km} / \mathrm{h}$ winds, in areas with high invasion rates vs. non-invaded areas (Fig. 4 and 5), fire fronts would advance 2.5 times faster $(9 \mathrm{~m} / \mathrm{min}$ vs. $22.1 \mathrm{~m} / \mathrm{min})$, the fire intensity would be 17.3 times greater $(569 \mathrm{KW} / \mathrm{m}$ vs. $9868 \mathrm{KW} / \mathrm{m})$, the flame length would be 2.8 times greater $(1.4 \mathrm{~m}$ vs. $5.3 \mathrm{~m}$ ), and the heat per unit area (independent of wind velocity) would be 7.1 times higher $\left(3792 \mathrm{Kj} / \mathrm{m}^{2}\right.$ vs. $\left.26778 \mathrm{Kj} / \mathrm{m}^{2}\right)$.

\section{Discussion}

Molasses grass greatly increased the fine fuel biomass in the campo-cerrado areas of the PESRM, potentially reaching values of up to $18 \mathrm{Mg} / \mathrm{ha}$, similar to the $12.1-21.4 \mathrm{Mg} / \mathrm{ha}$ estimated for a cerrado area with high rates of invasion in Brasília (Martins et al., 2011). The negative correlation between the biomasses of native monocots and those of molasses grass suggests that the former have been suppressed by the latter. This would also explain the reduction in the richness and abundance of eudicots, some of which are naturally rare. Conversely, eudicots persisted in small non-invaded patches within large areas invaded by molasses grass. Nitrogen use efficiency in molasses grass is known to be higher than is that of native South American C4 grasses (Lannes et al. 2012). Coutinho (2000) estimated that nearly $95 \%$ of nitrogen in burned cerrado plants is lost to the atmosphere as smoke. As a consequence, burned sites tend to be nitrogen deficient, with molasses grass often being the dominant species (Lannes et al. 2012). Furthermore, the competition for space and light, as well as allelopa-

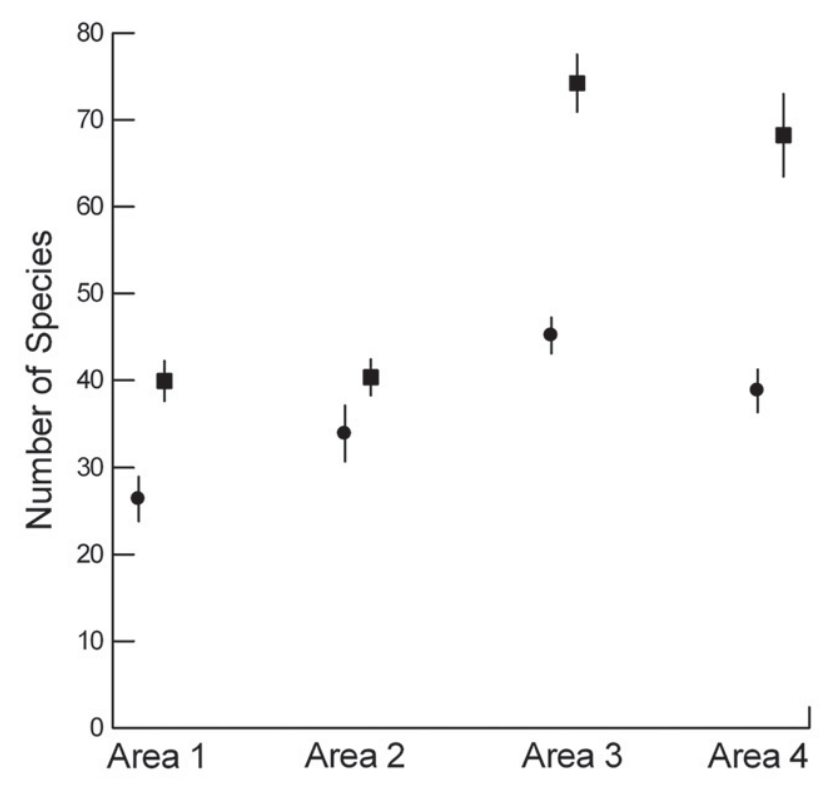

Figure 3. Comparison of species richness in non-invaded areas (circles) and areas invaded by molasses grass (squares). Richness was estimated using the abundance-based coverage estimator (ACE) index. t-test for all paired areas: $p<0.01$.

thy, changes in soil chemistry and accumulation of litter, are causal factors that affect smaller plants and seedlings (Corbin \& D'Antonio 2004; D’Antonio \& Vitousek 1992; Hamilton et al. 1999; Levine et al. 2003; Hoffmann et al. 2004; Hoffmann \& Haridasan 2008).

In the Cerrado Biome, natural fires are caused by lightning strikes and may be extinguished by subsequent rains. However, human activities have increased the risk of out-of-control fires during the dry season in protected areas (França et al. 2007), as is the case at the PESRM. In addition, the invasion of exotic grasses potentiates the grassfire cycle, characterized by more frequent and intense fires encompassing larger areas, due to the greater and faster accumulation of their biomass compared to that of the native species (D’Antonio \& Vitousek 1992; Milton 2004).

The fire simulations for the campo-cerrado at the PESRM indicated potentially greater fire intensity and flame length, with the chance of the fire spreading from the low herbaceous strata to the treetops increasing. The fire properties 
Table 2. Species sensitivity to molasses grass invasion.

\begin{tabular}{lccc}
\hline Species & $\begin{array}{c}\text { Individuals in } \\
\text { Non-Invaded Areas }\end{array}$ & $\begin{array}{c}\text { Individuals in } \\
\text { Invaded Areas }\end{array}$ & Suggestion \\
\hline Ageratum fastigiatum (Gardner) R.M.King \& H.Rob. & 58 & 12 & \\
Aspilia sp. & 72 & 13 & \\
Baccharis retusa DC. & 128 & 0 & Invasion sensibility study for molasses grass of those species \\
Baccharis sp. & 18 & 0 & \\
Solanum sp. & 17 & 0 & \\
Peixotoa tomentosa A. Juss. & 84 & 18 & \\
\hline Croton antisyphiliticus Mart. & 47 & 27 & Study of invasion sensibility and resistance study for molasses \\
\hline Baccharis dracucunlifolia DC. & 6 & 13 & \\
Hyptis lippioides Pohl ex Benth. & 25 & 22 & \\
Lippia sp. & 18 & 18 & Invasion resistance study for molasses grass of those species \\
Peltaea polymorpha (A. St.-Hil.) Krapov. \& Cristóbal & 1 & 19 & \\
Periandra mediterranea (Vell.) Taub. & 11 & 39 & \\
\hline
\end{tabular}
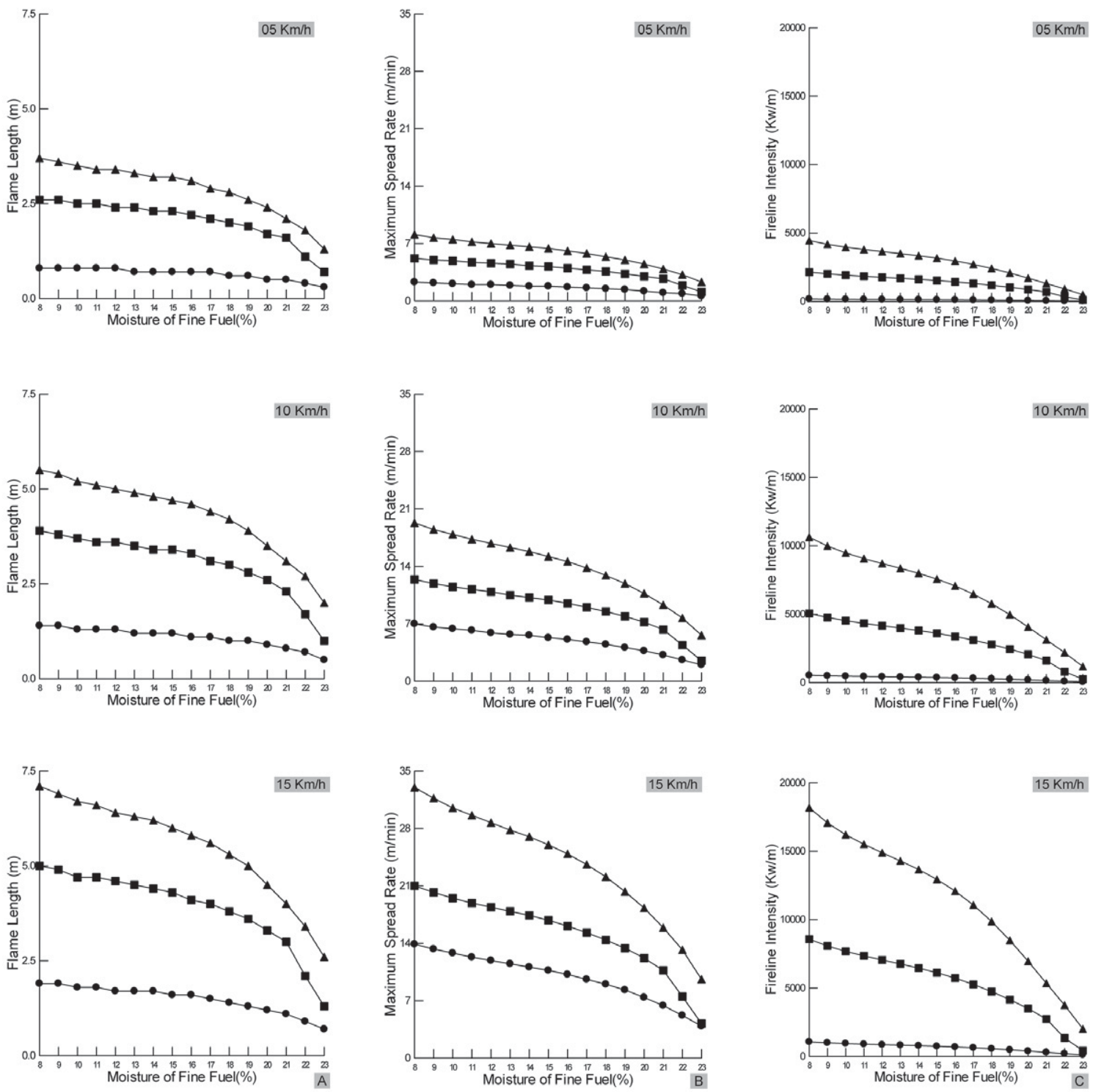

Figure 4. Flame length (a), maximum spread rate (b), and fire intensity (c) for different levels of invasion by molasses grass, with different levels of fine fuel moisture and at different wind speeds.

Triangles - high invasion rate; squares - intermediate invasion rate; circles - no invasion. 


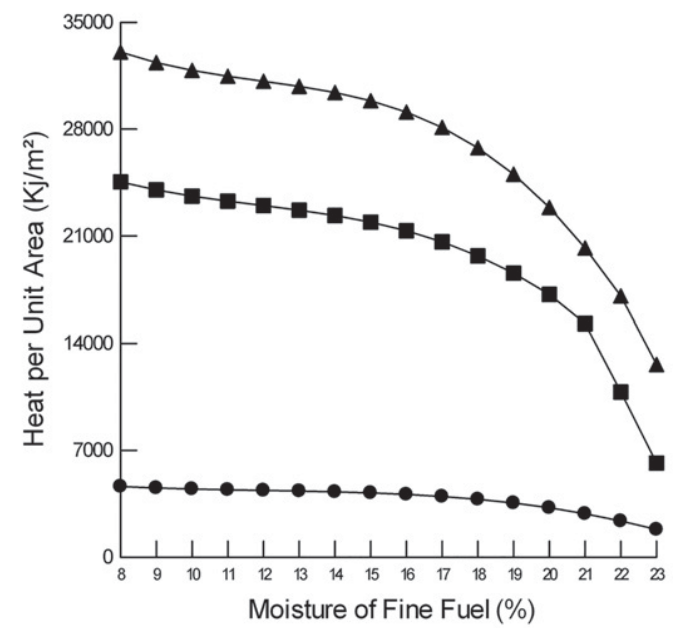

Figure 5. Heat per unit area for different levels of invasion by molasses grass, with different levels of fine fuel moisture.

Triangles - high invasion rate; squares - intermediate invasion rate; circles no invasion.

previewed by BehavePlus are compatible with other studies of the Cerrado Biome (Kauffman et al. 1994; Castro-Neves 2000). Eye-witness accounts from firefighters and volunteers of a large nine-day fire in this park at the end of the 2011 dry season, when 1949 ha $(\approx 60 \%)$ of the park area were burned, are impressive: flames $12 \mathrm{~m}$ high on the hilltops, invaded by molasses grass, had formed a huge fire front, and the heat could be felt from up to $200 \mathrm{~m}$ away. In the invaded valleys, the wind was channeled and the fire spread rapidly. Flame lengths surpassed $6 \mathrm{~m}$ (Rodrigo B. Belo, Director for Prevention and Control of Forest Fires and Critical Events, SEMAD). Charcoal marks on the valley trees showed signs of burning at a height $>5 \mathrm{~m}$, and some cerrado trees, like the "barbatimão" (Stryphnodendron adstringens (Mart.) Coville), appeared to be dead.

The results of our study corroborate those of other studies describing a reduction of native species diversity in areas invaded by molasses grass or other exotic grasses (D’Antonio \& Vitousek 1992; Hughes et al. 1991; Rahlao et al. 2009). Competition, changes in soil chemistry and fire can act synergistically, leading to a continuous species loss. Recurrent fires favor molasses grass at the expense of native monocots and eudicots that have less resistance to burning and less ability to regenerate (França et al. 2007). Control of molasses grass would be the only solution for a possible re-establishment of native vegetation in invaded preservation areas. At the Brasília National Park, such control was achieved by the combined use of controlled burning, herbicides and seedling removal (Martins et al. 2011). At the PESRM, the persistence of dense patches of molasses grass after decades of fire suppression demonstrates its ability to persist in the absence of such disturbance, as has been reported by other authors (Hughes et al. 1991; Berardi 1994).

The invasion of molasses grass in the campo-cerrado areas of the PESRM is increasing fire intensity, one of the major components of fire regimes (Brooks et al. 2004; Whelan 1995; Bond \& Wilgen 1996). In addition, molasses grass invasion increases the risk of fire and the chance of fire spreading from the grass layer to the treetops. Hoffmann $e t$ al. $(2004 ; 2009)$ predicted the retraction of gallery forests in the Cerrado Biome boundaries when fires are frequent. The increases in fire frequency and destructiveness associated with the invasion of molasses grass at the PESRM could reduce its gallery forests, bordered by the campo-cerrado, which sustain and protect one of the most important sources of fresh water for the metropolitan area (Euclydes 2011).

\section{Acknowledgments}

The authors are grateful to Claudia Jacobi, Paulina Maia Barbosa, Kátia Torres Ribeiro and Daniela Campos de Filippo, for their valuable suggestions and contributions to the original manuscript; to the former Director of the PESRM, Edmar Monteiro, and the research project managers of the Instituto Estadual de Florestas, Denize Fontes and Janaína Aguiar, for the research support provided; to Pedro Osório and Rafael Falci, for their help in the field; to Fernanda Caroline dos Santos, for helping with the screening; and to Paula Lara and Alex Popovkin, for improving the English-language version of this manuscript. This study received financial support from the Fundação de Amparo à Pesquisa do Estado de Minas Gerais (FAPEMIG, Foundation for the Support of Research in the State of Minas Gerais), from the Brazilian Coordenação de Aperfeiçoamento de Pessoal de Nivel Superior (CAPES, Office for the Advancement of Higher Education) and from the U.S. Fish \& Wildlife Service.

\section{References}

Alcântara, P.B. \& Bufarah, G. 1951. Plantas forrageiras: gramíneas e leguminosas. São Paulo, Nobel: Editora da Universidade de São Paulo. Andrews, P.L. 2009. BehavePlus fire modeling system, version 5.0: variables. Gen. Tech. Rep. RMRS-GTR-213WWW Revised. Fort Collins, CO: Department of Agriculture, Forest Service, Rocky Mountain Research Station. 111 p. Available from: http://www.fs.fed.us/rm/ pubs/rmrs_gtr213.pdf. Cited 2014 Jun 11.

Andrews, P.L. 2014. Current status and future needs of the BehavePlus fire modeling system. International Journal of Wildland Fire 23: 21-33.

Barger, N.N.; D’Antonio, C.M.; Ghneim, T. \& Cuevas, E. 2003. Constraints to colonization and growth of the African grass, Melinis minutiflora, in a Venezuelan savanna. Plant Ecology 167: 31-43.

Berardi, A. 1994. Effects of the African grass Melinis minutiflora on the plant community composition and the fire characteristics of a central Brazilian savanna. Thesis of Master of Science at University of London.

Biodiversitas, Fundação; Minas Gerais, Governo do Estado; SEMAD, Secretaria do Estado de Meio Ambiente e Desenvolvimento Sustentável; IEF, Instituto Estadual de Florestas; CUCO, Coordenação de Unidades de Conservação; CPVS, Coordenação de Proteção a Vida Silvestre; Rola-Moça, Gerência do Parque Estadual da Serra do Rola-Moça \& PROMATA. 2006. Plano de Manejo do Parque Estadual da Serra do Rola-Moça. Belo Horizonte. Minas Gerais.

Bond, W.J. \& Wilgen, B.W. 1996. Fire and plants. London, Chapman and Hall, (Volume 14 in the Population and Community biology series). 
Brooks, M.L.; D’Antonio, C.M.; Richardson, D.M.; Grace J.B.; Keeley, J.E.; DiTomaso, J.M.; Hoobs, R.J.; Pellant, M. \& Pyke, D. 2004. Effects of invasive alien plants on fire regimes. Bioscience 54 (7): 677-688.

Carmona, R. \& Martins, C.R. 2009. Efeito do local de coleta nas características de sementes de capim-gordura (Melinis minutiflora P. Beauv.) no Distrito Federal, Brasil. Revista Brasileira de Sementes 31 (3): 167-172.

Castro-Neves, B.M. 2000. Comportamento de queimadas, temperaturas do solo e recuperação da biomassa aérea em campo sujo nativo e em capim gordura (Melinis minutiflora). Dissertação de mestrado. Departamento de Ecologia da Universidade de Brasília.

Corbin, J.D. \& D'Antonio, C.M. 2004. Competition between native perennial and exotic annual grasses: implications for and historical invasion. Ecology 85 (5): 1273-1283.

Coutinho, L.M. 2000. O bioma Cerrado, Pp. 77-92. In: Klein, A.L. (Org). 2000. Eugen Warming e o Cerrado brasileiro: um século depois. Editora UNESP.

D’Antonio, C.M. \& Vitousek, P.M. 1992. Biological invasions by exotic grasses, the grass/fire cycle, and global change. Annual Reviews of Ecology and Systematics 23: 63-87.

Diamond, J.M. 1999. Guns, germs and steel: the fates of human societies. Norton paperback.

Dogra, K.S.; Sood, S.K.; Dobhal, P.K. \& Sharma, S. 2010. Alien plant invasion and their impact on indigenous species diversity at global scale: a review. Journal of Ecology and the Natural Environment 2 (9): 175-186.

Espíndola, M.B.; Bechara, F.C; Bazzo, M.S. \& Reis, A. 2005. Recuperação ambiental e contaminação biológica: aspectos ecológicos e legais. Biotemas 18 (1): 27-38

Euclydes, A.C.P. 2011. O que há de especial na proteção dos mananciais? Um estudo sobre as áreas de proteção especial - APEs - do eixo sul da região metropolitana de Belo Horizonte. Geografias 7 (1): 29-43.

Fearnside, P.M. 2005. Desmatamento na Amazônia brasileira: história, índice e conseqüências. Megadiversidade 1 (1): 113-123.

Fernandes, G.D.A. 2003. Simulação de incêndio florestal no parque estadual Serra do Rola-Moça, Minas Gerais, utilizando o farsite. Tese para obtenção de título "Magister Scientiae". Universidade Federal de Viçosa. Programa de Pós-Graduação em Ciência Florestal. Viçosa, Minas Gerais.

Filgueiras, T.S.; Longhi-Wagner, H.M.; Viana, P.L.; Zanin, A.; Guglieri, A.; Oliveira, R.C.; Canto-Dorow, T.S.; Shirasuna, R.T.; Valls, J.F.M. \& Oliveira, R.P. 2010. Poaceae. Pp. 1464-1520. In: Forzza, R.C.; Leitman, P.M.; Costa, A.F.; Carvalho Jr., A.A.; Peixoto, A.L.; Walter, B.M.T.; Bicudo, C.; Zappi, D.; Costa, D.P.; Lleras, E.; Martinelli, G.; Lima, H.C.; Prado, J.; Stehmann, J.R.; Baumgratz, J.F.A.; Pirani, J.R.; Sylvestre, L.; Maia, L.C.; Lohmann, L.G.; Queiroz, L.P.; Silveira, M.; Coelho, M.N.; Mamede, M.C.; Bastos, M.N.C.; Morim, M.P.; Barbosa, M.R.; Menezes, M.; Hopkins, M.; Secco, R.; Cavalcanti, T.B. \& Souza, V.C. (Org.). Lista de Espécies da Flora do Brasil. Rio de Janeiro, Jardim Botânico do Rio de Janeiro.

Foxcroft, L.C.; Richardson, D.M.; Rejmánek, M. \& Pysek, P. 2010. Alien plant invasions in tropical and sub-tropical savannas: patterns, processes and prospects. Biological Invasions 12: 3913-3933.

França, H.; Ramos-Neto, M.B. \& Setzer, A. 2007. O Fogo no Parque Nacional das Emas. Brasília, Ministério do Meio Ambiente. Série Biodiversidade, v. 27.

Gonçalves, L.C. \& Borges, I. 2006. Tópicos de Forragicultura Tropical. Belo Horizonte, FEPMVZ-Editora.

Hamilton, J.G.; Holzapfel, C. \& Mahall, B.E. 1999. Coexistence and interference between a native perennial grass and non-native annual grasses in California. Oecologia 121: 518-526.

Hoffmann, W.A.; Lucatelli, V.M.P.C.; Silva, F.J.; Azevedo I.N.C.; Marinho, M.S.; Albuquerque, A.M.S.; Lopes, A.O. \& Moreira, S.P. 2004. Impact of the invasive alien grass Melinis minutiflora at the savanna-forest ecotone in the Brazilian Cerrado. Diversity and Distributions 10 (2): 99-103.

Hoffmann, W.A. \& Haridasan, M. 2008. The invasive grass, Melinis minutiflora, inhibits tree regeneration in a neotropical savanna. Austral Ecology 33: 29-36.

Hoffmann, W.A.; Adasme, R.; Haridasan, M.; Carvalho, M.T.; Geiger, E.L.; Pereira, M.A.B.; Gotsch, S.G. \& Franco, A.C. 2009. Tree topkill, not mortality, governs the dynamics of savanna-forest boundaries under frequent fire in central Brazil. Ecology 90 (5): 1326-1337.

Hughes, F.; Vitousek, P.M. \& Tunison, T. 1991. Alien grass invasion and fire in the seasonal submontane zone of Hawai'i. Ecology 72 (2): 743-746.

Kauffman, J.B.; Cummings, D.L. \& Ward, D.E. 1994. Relationships of fire, biomass and nutrient dynamics along a vegetation gradient in the Brazilian cerrado. Journal of Ecology 82: 519-531.

Lannes, L.S.; Bustamante, M.M.C.; Edwards, P.J. \& Venterink, H.O. 2012. Alien and endangered plants in the Brazilian Cerrado exhibit contrasting relationships with vegetation biomass and $\mathrm{N}$ : $\mathrm{P}$ stoichiometry. New Phitologist 196 (3): 816-823.

Levine, J.M.; Vilà, M.; D’Antonio C.M.D.; Dukes, J.S.; Grigulis, K. \& Lavorel, S. 2003. Mechanisms underlying the impacts of exotic plant invasions. Proceedings of the Royal Society of London 270: 775-781

Martins, C.R.; Leite L.L. \& Haridasan, M. 2004. Capim-gordura (Melinis minutiflora P. Beauv.), uma gramínea exótica que compromete a recuperação de áreas degradadas em unidades de conservação. Revista Árvore 28: 739-747.

Martins, C.R. 2006. Caracterização e manejo da gramínea Melinis minutiflora P. Beauv. (capim-gordura): uma espécie invasora do cerrado. Tese de Doutorado. Programa de Pós-Graduação do Instituto de Biologia, Departamento de Ecologia da Universidade de Brasília, Distrito Federal.

Martins, C.R.; Hay, J.D.V. \& Carmona, R. 2009. Potencial invasor de duas cultivares de Melinis minutiflora no Cerrado brasileiro - características de sementes e estabelecimento de plântulas. Revista Árvore 33 (4): 713-722.

Martins, C.R.; Hay, J.D.V.; Walter, B.M.T.; Proença, C.E.B. \& Vivaldi, L.J. 2011. Impacto da invasão e do manejo do capim-gordura (Melinis minutiflora) sobre a riqueza e biomassa da flora nativa do Cerrado sentido restrito. Revista Brasileira de Botânica 34 (1): 73-90.

Milton, S.J. 2004. Grasses as invasive alien plants in South Africa. South African Journal of Science 100: 69-75.

Mistry, J. \& Berardi, A. 2005. Assessing fire potential in a Brazilian savanna nature reserve. Biotropica 37 (3): 439-451.

Parsons, J.J. 1972. Spread of African pasture grasses to the American tropics. The Journal of Range Management 25 (1): 12-17.

Pivello, V.R.; Shida, C.N. \& Meirelles, S.T. 1999a. Alien grasses in Brazilian savannas: a threat to the biodiversity. Biodiversity and Conservation 8: $1281-1294$

Pivello, V.R.; Carvalho, V.M.C; Lopes, P.F.; Peccinini, A.A \& Rosso, S. 1999b. Abundance and distribution of native and alien grasses in a "Cerrado" (Brazilian savanna) biological reserve. Biotropica 31 (1): 71-82.

Pivello, V.R. 2014. Invasões biológicas no cerrado brasileiro: efeitos da introdução de espécies exóticas sobre a biodiversidade. Ecologia. Info 33. Available from: http://www.ecologia.info/cerrado.htm. Cited 2014 May 18.

Prates, H.T.; Oliveira, A.B.; Leite, R.C. \& Craveiro, A.A. 1993. Atividade carrapaticida e composição química do óleo essencial do capim-gordura. Pesquisa Agropecuária Brasileira 28 (5): 621-625.

Rahlao, S.J.; Milton, S.J.; Esler, K.J.; Van Wilgen, B.W. \& Barnard, P. 2009. Effects of invasion of fire-free arid shrublands by a fire-promoting invasive alien grass (Pennisetum setaceum) in South Africa. Austral Ecology 34: 920-928.

Reis, A.; Bechara, F.C.; Espíndola, M.B.; Vieira, N.K. \& Souza, L.L. 2003. Restauração de áreas degradadas: a nucleação como base para incrementar os processos sucessionais. Natureza \& Conservação 1 (1): $28-36$.

Silva, J.S.O. \& Haridasan, M. 2007. Acúmulo de biomassa aérea e concentração de nutrientes em Melinis minutiflora P. Beauv. e gramíneas nativas do cerrado. Revista Brasileira de Botânica 30 (2): 337-344.

The Plant List. 2014. Versão 1.1. Available from: http://www.theplantlist. org. Cited 2014 Jun 10.

Whelan, R.J. 1995. The ecology of fire. Cambridge, Cambridge University Press.

Zanin, R. 2009. Aspectos da introdução das espécies exóticas: O capimgordura e a braquiária no Parque Nacional de Brasília. Dissertação de Mestrado. Centro de Desenvolvimento Sustentável. Universidade de Brasília, Brasília.

Zenni, R.D. \& Ziller, S.R. 2011. An overview of invasive plants in Brazil. Revista Brasileira de Botânica 34(3): 431-446. 